\title{
Tinjauan Yuridis Penyelesaian Sengketa Konsumen Akibat Penjualan Pupuk Bersubsidi Palsu
}

\author{
Unayah Pujawati, Grasia Kurniati \\ Fakultas Hukum, Universitas Singaperbangsa Karawang, Jl. HS.Ronggowaluyo Telukjambe Timur, Karawang \\ Correspondence email: 1710631010216@student.unsika.ac.id; grasia.kurniati@fh.unsika.ac.id
}

\begin{abstract}
Abstrak. Terbatasnya ketersediaan pupuk bersubsidi yang dijual di gerai kios resmi membuat sebagian petani kesulitan untuk mendapatkannya. Tak sedikit petani yang memutuskan untuk membeli pupuk bersubsidi di tempa lain yang tidak terjamin keasliannya. Akibatnya ada beberapa petani yang tertipu oleh penjual pupuk bersubsidi palsu. Karena itu dibuatlah sebuah ketentuan hukum untuk melindungi hak-hak petani sebagai konsumen, dan untuk membuat penjual pupuk bersubsidi palsu jera dengan tindakan yang dilakukannya. Pelaku usaha juga harus bertanggung jawab atas konsekuensi terhadap kerugian yang dialami konsumen. Penelitian ini bertujuan untuk mengetahui faktor penyebab terjadinya penjualan pupuk bersusidi palsu dan bagaimana mekanisme penyelesaian sengketa konsumen akibat penjualan pupuk palsu berdasarkan Undang-Undang Nomor 8 Tahun 1999 tentang Perlindungan Konsumen. metode penelitian yang digunakan adalah yuridis normatif. Hasil penelitian menemukan bahwa faktor penyebab terjadinya penjualan pupuk bersubsidi palsu adalah kurangnya kehati-hatian konsumen dalam pembelian pupuk bersubsidi, tidak adanya tanggung jawab pelaku usaha, dan kemudahan dalam mendapatkan bahan baku pembuatan pupuk palsu. Penyelesaian sengketa konsumen sebagai pelindungan hukum bagi petani dapat ditempuh melalui tida tahapan yaitu konsiliasi, mediasi, dan arbitrase.
\end{abstract}

\section{Kata Kunci: Pupuk Bersubsidi, Pupuk Palsu, dan Petani}

\begin{abstract}
The limited availability of subsidized fertilizers sold at official kiosk outlets makes it difficult for some farmers to get them. Not a few farmers who decide to buy subsidized fertilizer in other places whose authenticity is not guaranteed. As a result there are some farmers who are deceived by sellers of fake subsidized fertilizers. Therefore, a legal provision was made to protect the rights of farmers as consumers, and to deter sellers of fake subsidized fertilizers from taking action. Business actors must also be responsible for the consequences of losses suffered by consumers. This study aims to determine the factors causing the sale of counterfeit fertilizers and how the mechanism for resolving consumer disputes due to the sale of counterfeit fertilizers is based on Law Number 8 of 1999 concerning Consumer Protection. the research method used is normative juridical. The results of the study found that the factors that caused the sale of fake subsidized fertilizers were the lack of caution of consumers in purchasing subsidized fertilizers, the absence of responsibility for business actors, and the ease of obtaining raw materials for making fake fertilizers. Settlement of consumer disputes as legal protection for farmers can be reached through three stages, namely conciliation, mediation, and arbitration.
\end{abstract}

Keywords : Subsidized Fertilizer, Fake Fertilizer, and Farmers

\section{PENDAHULUAN}

Negara Indonesia merupakan suatu negara hukum sehingga apapun kegiatan yang dilakukan oleh masyarakatnya merupakan kegiatan yang hidup dan harus berpedoman pada peraturan dan norma yang berlaku di masyarakat. Kehidupan manusia tidak dapat dipisahkan dari hukum, karena hukum merupakan aturan yang mengatur perilaku manusia dalam kehidupan. Setiap individu dalam kehidupan bermasyarakat dan segala perilakunya diatur oleh hukum, salah satunya yaitu hukum yang telah diatur dan dibuat oleh Pemerintah.

Dalam kesehariannya kegiatan bisnis mempunyai keterkaitan erat di lingkungan pelaku usaha dan konsumen. Keuntungan yang diperoleh pelaku usaha sangat penting untuk melakukan transaksi dengan konsumen, sedangkan bagi kepentingan konsumen kepuasan akan ada apabila kebutuhan produk tertentu telah terpenuhi. Faktor utama yang menyebabkan munculnya masalah bagi konsumen seringkali diakibatkan oleh rendahnya tingkat kesadaran yang dimiliki oleh konsumen akan hak-haknya, situasi ini membuat pelaku usaha memanfaatkannya dengan sebaik mungkin untuk memperoleh keuntungan yang besar tanpa memperhatikan kewajiban yang seharusnya ada pada diri pelaku usaha baik secara langsung maupun tidak langsung. Untuk itu diperlukan adanya keseimbangan antara upaya perlindungan konsumen terhadap risiko yang terjadi akibat kerugian yang diperoleh dalam penggunaan jasa maupun barang melalui upaya pencegahan dari ketidakpastian kualitas, kuantitas dan keamanan. ${ }^{1}$

Untuk memenuhi kebutuhan hidup manusia diperlukannya tanaman ataupun sayuran guna bertahan hidup adapun pupuk menjadi salah satu bahan kimia ataupun organisme yang mempunyai peran dengan cara menyediakan 
unsur hara bagi kebutuhan tanaman secara langsung maupun tidak langsung. ${ }^{2} \mathrm{Hal}$ ini sangat berguna bagi petani untuk mendukung pertumbuhan dan perkembangan tanaman. Terbatasnya jumlah pupuk bersubsidi yang dijual menyulitkan sebagian petani untuk membelinya. Tidak sedikit petani yang membeli pupuk bersubsidi pada orang yang tidak dikenal yang berakhir membeli pupuk palsu. Maka dari itu dibutuhkan perlindungan konsumen, yaitu perangkat hukum yang dirancang untuk melindungi semua hak konsumen. Yang dimaksud dengan perlindungan konsumen adalah segala upaya yang menjamin kepastian hukum untuk memberikan perlindungan kepada konsumen.

Berdasarkan ketentuan pada Pasal 4 Undang-Undang Nomor 8 Tahun 1999 tentang Perlindungan Konsumen hak yang utama bagi konsumen adalah hak atas keamanan produk, hak atas informasi, hak atas perlindungan dan upaya penyelesaian sengketa perlindungan konsumen serta hak untuk mendapatkan kompensasi dalam bentuk ganti rugi. Namun dengan adanya penjualan pupuk palsu yang tidak sesuai standar dan kebutuhan petani yang akhirnya menyebabkan kerugian bagi konsumen akibat menggunakan pupuk palsu dan membuat tanaman padi menjadi rusak dan terancam gagal panen.

Berdasarkan uraian diatas, penulis tertarik untuk meneliti lebih lanjut tentang apa saja faktor penyebab terjadinya penjualan pupuk bersubsidi palsu hingga bagaimana mekanisme penyelesaian sengketa konsumen akibat penjualan pupuk bersubsidi palsu berdasarkan Pasal 45 Undang-Undang Nomor 8 Tahun 1999 tentang Perlindungan Konsumen.

\section{METODE}

Untuk dapat menemukan suatu permasalahan maka diperlukan suatu pendekatan dengan menggunakan metode ilmiah tertentu. Metode penelitian yang digunakan dalam penulisan ini adalah sebagai berikut:

1. Pendekatan penelitian

Bentuk-bentuk pendekatan penelitian yang digunakan adalah pendekatan peraturan perundang-undangan, teori, sejarah, perbandingan, kasus, konsep, sosiologis dan lain-lain.

2. Metode penelitian

Dalam penelitian ini penulis menggunakan metode penelitian yuridis normatif, yaitu penelitian yang hanya dilakukan dengan cara menelaah norma hukum yang ada dalam suatu perundang-undangan. ${ }^{3}$

3. Spesifikasi penelitian

Spesifikasi penelitian yang digunakan adalah deskriptif analisis, yaitu mendeskripsikan dan menganalisis permasalahan secara deskriptif, rinci dan menyeluruh dari data dan informasi yang diperoleh mengenai hukum perlindungan konsumen.

4. Jenis dan Sumber data

Dalam penulisan ini menggunakan jenis dan sumber data sekunder yaitu jenis data yang diperoleh dari hasil studi kepustakaan, yang terdiri dari :

a. Bahan hukum primer, yaitu bahan hukum yang memuat peraturan perundang-undangan, dalam hal ini bahan hukum yang digunakan adalah Undang-Undang Nomor 8 Tahun 1999 tentang Perlidungan Konsumen.

b. Bahan hukum sekunder, yakni bahan hukum yang memberikan penjelasan tentang bahan hukum primer seperti halnya buku-buku, karya tulis ilmiah, dan dokumen-dokumen lain yang berkaitan dengan penulisan ini.

c. Bahan hukum tersier, yakni bahan hukum yang memberikan pedoman dan penjelasan mengenai bahan hukum primer dan sekunder yaitu kamus hukum dan ensiklopedia.

5. Teknik pengumpulan data

Teknik pegumpulan data yang digunakan didalam penulisan merupakan studi kepustakaan yaitu metode pengumpulan data pustaka yang memanfaatkan sumber kepustakaan untuk memeproleh data penelitian.

6. Teknik analisis data

Analisis data yang digunakan dalam penulisan ini berupa data kualitatif, artinya mendeskripsikan data secara berkualitas dalam bentuk kalimat yang teratur, runtun, logis, tidak tumpang tindih dan efektif sehingga memudahkan interpretasi data dan pemahaman hasil analisis ${ }^{4}$.

\section{HASIL DAN PEMBAHASAN}

Berdasarkan Teori Perlindungan Kosumen penulis memakai prinsip-prinsip mengenai kedudukan konsumen serta hubungannya dengan pelaku usaha berdasarkan teori hukum perlindungan konsumen, diantaranya:

\footnotetext{
2 Kementrian Pertanian, Pedoman Pengawasan Pupuk dan Pestisida Tahun 2019, (Direktorat Jenderal Prasarana dan Sarana Pertanian 2019), hlm. 3.

${ }^{3}$ Sri Mamudji, dkk, Metode Penelitian dan Penulisan Hukum, (Jakarta: Badan Penerbit Fakultas Hukum Universitas Indonesia, 2005), hlm. 10.

${ }^{4}$ Abdulkadir Muhammad, Hukum dan Penelitian Hukum, (Bandung: PT. Citra Aditya Bakti, 2004), hlm. 127.
} 
1. Let the buyer beware, yang menjadi dasar dari lahirnya sengketa dibidang transaksi konsumen. Prinsip ini mengasumsikan bahwa pelaku usaha dan konsumen merupakan pihak yang sangat seimbang, sehingga konsumen tidak memerlukan perlindungan. Prinsip ini merupakan kelemahan, bahwa dalam perkembangannya konsumen tidak mendapatkan informasi yang cukup untuk menentukan pilihan terhadap barang maupun jasa yang dikonsumsinya. Hal ini dapat disebabkan oleh keterbatasan pengetahuan konsumen atau tidak terbukanya pelaku usaha terhadap produk yang ditawarkan. Dengan demikian hubungan konsumen mengalami kerugian, sehingga pelaku usaha dapat berpendapat bahwa kerugian tersebut akibat dari kelalaian konsumen.

2. The due care theory, yang merupakan kewajiban pelaku usaha untuk berhati-hati dalam memasarkan produk, baik barang maupun jasa. Selama pelaku usaha berhati-hati dengan produknya, maka tidak bisa disalahkan. Dalam prinsip ini berlaku pembuktian untuk siapa yang berpendapat maka dialah yang membuktikan. Hal ini sesuai dengan yang terdapat pada pembuktian hukum privat di Indonesia yaitu pembuktian ada pada penggugat, sesuai dengan Pasal 1865 BW yang secara tegas menyatakan bahwa siapapun yang mendalilkan berhak atau mengukuhkan haknya atau membngingkari hak orang lain, atau menunjuk pada suatu peristiwa, maka wajib membuktikan adanya hak atau peristiwa tersebut.

\section{Faktor Penyebab Terjadinya Penjualan Pupuk Bersubsidi Palsu}

Petani yang dikenal sebagai seorang yang bergerak di bidang pertanian, terutama dalam mengelola lahan yang bertujuan untuk bercocok tanam dan memelihara tanaman seperti halnya padi, bunga, buah dan lain-lain dengan harapan dapat memperoleh hasil dari tanaman tersebut untuk digunakan secara pribadi ataupun untuk dijual kepada pihak lain. Pertanian memiliki peran penting dalam perekonomian karena berdampak langsung terhadap kebutuhan pokok masyarakat di Indonesia khususnya padi. ${ }^{5}$ Dalam melakukan kegiatan bercocok tanam pertanian tentu saja petani membutuhkan pupuk, dikarenakan pupuk mempunyai perananan yang sangat penting untuk memudahkan dalam mendukung pertumbuhan dan perkembangan tanamannya. Kemudahan untuk mendapatkan pupuk petani didukung dengan adanya program pupuk bersubsidi yang dibuat oleh pemerintah yang disinyalir dapat memudahkan petani dalam mendapatkan pupuk dan dengan harga yang terjangkau. Tapi sayangnya program pupuk bersubsidi yang berasal dari pemerintah tidak dapat menutupi kurangnya pupuk yang dibutuhkan petani untuk keperluan pertanian. Dari sini mulai bermunculan pelaku usaha nakal dengan cara memproduksi pupuk bersubsidi palsu yang dijual dengan harga murah untuk mengelabui petani. Pupuk Palsu sendiri merupakan pupuk yang mutu atau kandungannya belum sesuai dengan label maupun merek yang ada pada pupuk, wadah kemasan berlabel yang meniru pupuk bersubsidi lain yang telah diedarkan secara sah. Artinya keberadaan pupuk bersubsidi palsu adalah produk tidak legal yang dijual di pasaran. ${ }^{6}$

Faktor yang menyebabkan terjadinya penjualan pupuk palsu di pasaran diantaranya adalah kurangnya kehatihatian petani dalam melakukan sebuah pembelian barang, tidak adanya tanggung jawab yang diberikan pelaku usaha, dan kemudahan dalam mendapatkan bahan baku untuk pembuatan pupuk palsu. Salah satu penyebab kurangnya kehati-hatian petani adalah masih banyaknya petani yang kesulitan secara ekonomi dan mengandalkan pupuk bersubsidi pemerintah untuk meningkatkan produktivitas pertanian yang sayangnya telah terjadi kelangkaan pupuk. Hal tersebut menyebabkan petani menjadi mudah tergiur oleh pupuk bersubsidi yang dijual dengan harga terjangkau karena sulitnya mendapatkan pupuk bersubsidi. Padahal pupuk bersubsidi yang terjamin keasliannya hanya dijual di gerai kios resmi. Dari situlah banyak oknum-oknum tidak bertanggung jawab berani memanfaatkan kondisi ini dengan ide menjual pupuk bersubsidi palsu guna meraup keuntungan berlebih.

Belakangan ini marak pemberitaan yang terdapat pada media cetak seperi halnya koran maupun elektronik berkenaan dengan adanya infiltrasi pupuk tidak legal dibidang pertanian. Peredaran pupuk bersubsidi palsu membuat pemerintah dan masyarakat menjadi resah. Pupuk bersubsidi palsu yang digunakan dalam budidaya tanaman yang tidak teridentifikasi sejak dini akan menyebabkan timbulnya permasalahan yang lebih kompleks, bukan hanya ketidakefisienan, penurunan pendapatan, permasalahan hukum, namun juga bisa menyebebkan terjadinya kerusakan lingkungan. Sehingga jika masalah pupuk bersubsidi palsu tidak segera ditangani dengan baik maka kerugian yang ditimbulkannya menjadi sangat besar seperti yang terjadi pada daerah Jatisari bahwasannya telah terjadi pelanggaran penjualan pupuk bersubsidi palsu. Hal tersebut disebabkan banyaknya petani yang tergiur untuk membeli pupuk bersubsidi dengan harga yang lebih murah. Pasalnya, harga pupuk bersubsidi di gerai kios resmi dijual dengan harga yang disesuaikan dan dengan stok terbatas karena merupakan barang yang berasal dari Pemerintah. Selain itu, hasil panen petani yang sebelumnya dijual dengan harga murah karena cuaca yang tidak menentu seperti hujan yang turun

${ }^{5}$ Nini Rigi, Syahrana Raesi, dan Rafnel Azhari, “Analisis Efektivitas Kebijakan Pupuk Bersubsidi Bagi Petani Di Nagari Cupak Kecamatan Gunung Talang Kabupaten Solok", JOSETA: Journal Of Socio Economic on Tropical Agriculture, Vol. 1 No. 3, (Desember 2019): 75-83.

${ }^{6}$ Kementrian Pertanian, Pedoman Pengawasan Pupuk dan Pestisida Tahun 2019, (Direktorat Jenderal Prasarana dan Sarana Pertanian 2019), hlm. 6. 
terus menerus. Disini para petani memeras otak, bagaimana menggunakan modal yang diterima dari panen kemarin agar cukup untuk kebutuhan bertani selanjutnya dan untuk biaya hidup sehari-hari. Atas dasar itulah penulis memaparkan bahwa petani membutuhkan langkah-langkah perlindungan hukum yang dapat ditempuh melalui jalur hukum agar pelanggaran serupa tidak terulang kembali.

Dengan diadakannya pupuk tidak legal khususnya pupuk bersubsidi palsu dibuat dengan sengaja oleh pelaku usaha yang tidak memperdulikan tanggung jawab yang tujuannya untuk mencari keuntungan. Salah satunya dikarenakan masalah pupuk bersubsidi palsu seringkali terjadi karena adanya penyebab yang memicu yaitu masalah perbedaan dalam menentukan harga pupuk dan kebutuhan pupuk bersubsidi yang sangat besar. Selisih harga pupuk untuk jenis pupuk serupa yaitu antara pupuk bersubsidi dan pupuk tidak bersubsidi dijadikan sebagai sarana untuk memperoleh keuntungan. Situasi ini diperparah dengan kebutuhan pupuk dalam waktu yang singkat seperti saat musim pemupukan, kebutuhan serentak serta sering terjadi situasi ketika terjadi kelangkaan pupuk. Faktor lainnya yaitu adanya pupuk bersubsidi yang dipalsukan dan didorong oleh kemudahan dalam memproduksi pupuk serta tersedianya bahan baku mudah dapat yang digunakan untuk pemalsuan pupuk di lapangan.

Diadakannya tindakan pencegahan dan pengendalian sosial dilakukan aparat keamanan untuk upaya penekanan dalam penggunaan pupuk tidak legal dan pupuk bersubsidi palsu. Upaya pengawasan distribusi atau pemasaran pupuk dan regulasi dibidang pemupukan serta landasan hukum yang mendasarinya terus ditingkatkan. Adanya pemalsuan pupuk seakan dianggap menjadi hal yang sangat lumrah, seakan-akan segala upaya untuk menekan aksi jual pupuk bersubsidi palsu tidak membuahkan hasil. Tindakan pencegahan dengan cara deteksi sedini mungkin untuk mengetahui keberadaan pupuk bersubsidi palsu tampaknya menjadi salah satu cara paling efektif. Untuk mendeteksi pupuk palsu terdapat banyak cara yang bisa dilakukan. Baik dilakukan secara modern maupun secara sederhana. Studi kasus mengenai adanya kejadian dalam memalsukan pupuk bersubsidi harus digunakan sebagai pengalaman untuk memilah metode ataupun cara mengidentifikasi secara bijaksana. ${ }^{7}$

\section{Mekanisme Penyelesaian Sengketa Konsumen Akibat Penjualan Pupuk Palsu}

Upaya penyelesaian sengketa konsumen berdasarkan ketentuan Undang-Undang Nomor 8 Tahun 1999 tentang Perlindungan Konsumen tidak adanya suatu definisi yang jelas mengenai sengketa konsumen itu sendiri. Namun suatu sengketa (conflict, dispute) secara pasti bisa terjadi kapan saja diantara konsumen dan pelaku usaha. Selain merusak, sengketa pun merugikan hubungan antara konsumen dengan pelaku usaha. Karenanya, sengketa yang melibatkan pihak-pihak tersebut harus diselesaikan sepenuhnya. Suatu sengketa konsumen berdasarkan Undang-Undang Nomor 8 Tahun 1999 tentang Perlindungan Konsumen dapat diselesaikan melalui dua cara:

a. Pengadilan, yaitu apabila ada konsumen terlibat suatu sengketa yang merugikan konsumen dapat menyelesaikan sengketanya melalui lembaga peradilan umum. Hal ini mengacu pada ketentuan tentang peradilan umum yang berlaku dengan memperhatikan pada Pasal 45 Undang-Undang Nomor 8 Tahun 1999 tentang Perlindungan Konsumen.

b. Luar pengadilan, yaitu apabila terjadi suatu sengketa konsumen selain dapat terselesaikan melalui lembaga pengadilan, dapat pula terselesaikan di luar lembaga pengadilan yaitu melalui Badan Penyelesaian Sengketa Konsumen. Jika telah memilih upaya penyelesaian sengketa konsumen di luar lembaga pengadilan, gugatan hanya dapat ditempuh melalui lembaga pengadilan. Jika upaya tersebut masih saja belum berhasil oleh salah satu pihak atau oleh para pihak yang bersengketa. Maka penyelesaian suatu sengketa diluar lembaga pengadilan melalui BPSK ini tidak dapat menghilangkan tanggung jawab pidana.

Penyelesaian sengketa yang terjadi antara konsumen dan pelaku usaha dapat diselesaikan melalui jalur litigasi (pengadilan) dan nonlitigasi (di luar pengadilan). Penyelesaian melalui lembaga litigasi dinilai kurang efisien dari segi waktu, biaya, dan tenaga, sehingga penyelesaian melalui lembaga non litigasi banyak dipilih oleh masyarakat dalam menyelesaikan sengketa yang bersangkutan. Namun, pengadilan tetap akan menjadi pilihan terakhir jika di tingkat non-litigasi tidak ada kesepakatan. ${ }^{8}$

\section{Badan Penyelesaian Sengketa Konsumen (BPSK)}

Pasal 49 Undang-Undang Nomor 8 Tahun 1999 tentang Perlindungan Konsumen menyatakan bahwa untuk menyelesaikan suatu sengketa konsumen yang terjadi diluar lembaga pengadilan dibuatlah Badan Penyelesaian

${ }^{7}$ Mohamad Mulyadi dan M. Edi Premono. "Pupuk Palsu : Penyebaran, Identifikasi Dan Dampaknya Terhadap Usaha Perkebunan", https://saraswantifertilizer.com/pupuk-palsu-penyebaran-identifikasi-dan-dampaknya-terhadap-usaha-perkebunan/, PT. Saraswanti Anugerah Makmur - Saraswanti Group, (April 2018).

${ }^{8}$ Mairul dan Kartika Dewi Irianto, "Penyelesaian Sengketa Konsumen Melalui Jalur Non Litigasi (Studi pada Badan Penyelesaian Sengketa Konsumen (BPSK) dan Lembaga Alternatif Penyelesaian Sengketa (LAPS))", PAGARUYUANG Law Journal, Vol. 1, No. 2, (Januari 2018): P-ISSN: 2580-4227, E-ISSN: 2580-698X. 
Sengketa Konsumen oleh Pemerintah untuk daerah kabupaten/kota. Keanggotaannya ini terdiri dari tiga unsur yaitu unsur pemerintah, konsumen, dan pelaku usaha. Pelaksanaan tugas dan wewenang badan penyelesaian sengketa konsumen termasuk melaksanakan penanganan dan penyelesaian sengketa konsumen melalui konsiliasi, mediasi dan arbitrase, juga memberikan konsultasi perlindungan hukum, melakukan pelaporan yang ditujukan kepada penyidik umum tekait terjadinya pelanggaran, dapat menerima pengaduan tertulis maupun tidak tertulis, melakukan penelitian dan pemeriksaan sengketa, melakukan panggilan kepada pelaku usaha yang diduga melakukan pelanggaran, memanggil dan menghadirkan saksi, saksi ahli atau orang yang mengetahui terkait pelanggaran dan dapat meminta bantuan kepada penyidik untuk yang ditujukan kepada pihak yang tidak bersedia memenuhi panggilan BPSK. Dari situ kita dapat memperoleh, memeriksa, menilai surat, dokumen atau bukti lain untuk penyelidikan serta pemeriksaan yang dapat memutuskan dan menentukan apakah terdapat kerugian di pihak konsumen dan memutuskan apakah akan dikenakan sanksi administratif kepada pelaku usaha yang melanggar ketentuan Undang-Undang Perlindungan Konsumen.

Instrumen hukum penyelesaian sengketa konsumen pada Badan Penyelesaian Sengketa Konsumen di luar pengadilan, dengan cara :

a. Konsiliasi

Konsiliasi merupakan salah satu alternatif penyelesaian sengketa yang dilakukan di luar pengadilan. Pada buku Alternatif Penyelesaian Sengketa dan Arbitrase yang ditulis oleh Endrik Safudin dijelaskan bahwa konsiliasi adalah salah satu bentuk penyelesaian sengketa di luar pengadilan dengan bantuan pihak ketiga atau konsiliator. ${ }^{9}$ Dikutip dari Dictionary of Law Complete Edition dijelaskan bahwa konsiliasi merupakan upaya mempertemukan keinginan para pihak yang bersengketa untuk mencapai kesepakatan guna menyelesaikan sengketa dengan cara kekeluargaan. ${ }^{10}$

Pihak ketiga dalam konsiliasi berbeda dengan pihak ketiga dalam mediasi, karena konsiliator lebih aktif daripada mediator. Konsiliator tidak hanya bertugas sebagai fasilitator, seperti mediator, tetapi juga bertugas menyampaikan pendapat tentang suatu masalah, memberikan saran yang mencakup kelebihan dan kekurangan, serta berupaya mencapai kesepakatan dengan para pihak yang bersengketa untuk menyelesaikan perselisihan.

Penyelesaian sengketa yang inisiatifnya datang dari satu pihak atau para pihak dengan didampingi oleh Majelis BPSK sebagai konsiliator atau perantara yang pasif sifatnya. Sebagai pemerantara antara para pihak yang bersengketa, Majelis BPSK bertugas dalam memanggil konsumen dan pelaku usaha yang bersengketa, memanggil saksi dan saksi ahli bila diperlukan, menyediakan wadah bagi konsumen dan pelaku usaha yang bersengketa dan menanggapi pernyataan konsumen dan pelaku usaha tentang peraturan perundang-undangan di bidang perlindungan konsumen.

Terdapat dua prinsip prosedur penyelesaian sengketa konsumen, yang pertama yaitu proses penyelesaian sengketa konsumen menyangkut para pihak sedangkan Majelis BPSK bertindak pasif sebagai konsiliator. Kedua, hasil musyawarah konsumen dan pelaku usaha dikeluarkan dalam bentuk keputusan dan penyelesaian sengketa konsumen.

b. Mediasi

Mediasi merupakan sebuah proses negosiasi penyelesaian sengketa atau penyelesaian masalah dimana pihak ketiga yang tidak memihak bekerja sama dengan para pihak yang bersengketa untuk membantu memperoleh kesepakatan yang memuaskan. Yang membantu para pihak melakukan mediasi disebut sebagai mediator. Mediator sendiri tidak memiliki kewenangan untuk memutuskan sengketa. Mediator hanya membantu para pihak untuk menyelesaikan masalah yang telah diajukan kepada mereka. Dalam suatu sengketa dimana adanya pihak yang lebih kuat dan terbiasa menunjukkan kekuasaannya, disini pihak ketiga berperan penting untuk penyetarannya. Kesepakatan bisa dicapai melalui proses mediasi jika kesepahaman dapat dicapai oleh para pihak yang bersengketa dan penyelesaian perselisihan dapat dirumuskan dengan adanya arahan mediator.

Penyelesaian sengketa melalui proses mediasi dilakukan sendiri oleh para pihak yang bersengketa sendiri dengan didampingi oleh seorang mediator. Disini mediator menyerahkan sepenuhnya proses penyelesaian sengketa kepada pihak-pihak baik mengenai bentuknya maupun besarnya ganti rugi atau tindakan tertentu dengan memastikan kerugian konsumen tidak terulang kembali. Dibandingkan penyelesaian sengketa yang melalui proses konsiliasi, tentunya mediator dalam proses mediasi menjadi lebih aktif dengan memberikan nasehat, arahan, saran dan cara lain lain untuk menyelesaikan sengketa sesuai ketentuan yang ada pada Pasal 1 Undang-Undang Nomor 30 tahun 1999 tentang Arbitrase dan Alternatif penyelesaian sengketa.

Untuk menentapkan jadwal pertemuan dalam penyelesaian proses mediasi merupakan kewajiban dari pihak moderator. Jika dipandang perlu, mediator dapat melakukan proses penyelesaian sengketa melalui mediasi dengan

\footnotetext{
${ }^{9}$ Endrik Safudin, Alternatif Penyelesaian Sengketa dan Arbitrase, (Jakarta: Instrans Publicing, 2017), hlm. 60.

${ }^{10}$ Drs. M. Marwan, S.H, \& Jimmy P, S.H, Dictionary of Law Complete Edition Reality, , (Yogyakarta: Reality Publiher,
} 2017), hlm. 62. 
kasus tertentu bisa dilakukan proses mediasi secara terpisah baik antar pelaku usaha maupun konsumen. Hal ini perlu dilakukan jika para pihak sulit untuk melakukan rekonsiliasi. Kemampuan dan pengalaman mediator diharapkan dapat memperlancar proses mediasi anatar pihak yang bersengketa. ${ }^{11}$

Begitu pula dalam proses konsiliasi dan proses mediasi berdasarkan permintaan para pihak, mediator dapat meminta untuk menunjukkan bukti-bukti, baik surat ataupun dokumen lain yang mendukung kedua belah pihak. Mediator dapat mengundang saksi lebih dari satu dan saksi ahli di bidang tertentu untuk menjelaskan tentang suatu hal yang berterkaitan dengan sengketa apabila mendapat persetujuan para pihak atau kuasanya. Jika kesepakatan dapat diperloleh dari hasil mediasi maka para pihak yang dibantu oleh mediator diwajibkan untuk merumuskan kesepakatan yang dicapai dan ditandatangani oleh para pihak.

Peran majelis BPSK dalam penyelesaian sengketa konsumen melalui mediasi dalam uraian, meliputi tugasnya adalah melakukan pemanggilan konsumen dan pelaku usaha yang bersengketa serta melakukan pemanggilan saksi dan saksi ahli bila diperlukan, menyediakan wadah bagi konsumen dan pelaku usaha yang bersengketa dan secara aktif melakukan rekonsiliasi. Kedua pihak yang bersengketa, serta aktif memberikan saran atau rekomendasi penyelesaian sengketa konsumen sesuai dengan ketentuan peraturan perundang-undangan di bidang perlindungan konsumen.

Hasil dari dilakukannya musyawarah yaitu berupa kesepakatan antara konsumen dan pelaku usaha yang bersengketa kemudian dibuatkan kesepakatan tertulis yang ditandatangani para pihak dan disampaikan kepada majelis BPSK untuk memperkuat kesepakatan. Keputusan yang dibuat bersifat mengikat kedua belah pihak. Sanksi administratif tidak dimuat dalam keputusan majelis konsiliasi dan mediasi.

c. Arbitrase

Arbitrase merupakan cara untuk menyelesaikan sengketa perdata di luar lembaga pengadilan yang pada dasarnya ada dalam perjanjian arbitrase dan secara tertulis dibuat oleh para pihak yang bersengketa. Arbitrase disebutkan menjadi satu dari banyaknya lembaga alternatif penyelesaian sengketa dari sekian banyak alternatif yang paling formal sebelum menempuh jalur hukum. Dalam proses ini, pihak yang bersengketa menyampaikan kekhawatiran mereka kepada pihak ketiga yang netral dan memberi mereka wewenang untuk mengambil keputusan.

Berdasarkan definisi tersebut, lembaga arbitrase hanya dapat menyelesaikan dan memutus perkara perdata saja. Sebagaimana dimaksud dalam undang-undang tersebut, perjanjian arbitrase merupakan suatu perjanjian dalam bentuk klausul arbitrase yang dituangkan dalam perjanjian tertulis yang dibuat oleh para pihak sebelum timbul nya suatu sengketa atau perjanjian arbitrase tersendiri yang dibuat oleh para pihak setelah munculnya sengketa. ${ }^{12}$

Penyelesaian sengketa melalui arbitrase cenderung lebih santai dan lebih sederhana daripada proses litigasi, prosedurnya tidak terlalu kaku dan lebih mudah beradaptasi serta lebih jarang terjadi penundaan. Jika dibandingkan dengan proses penyelesaian sengketa melalui lembaga peradilan, lembaga arbitrase memiliki beberapa keunggulan, diantaranya berupa kerahasiaan sengketa para pihak dijamin, penundaan yang dapat dihindari karena suatu permasalahan prosedur dan administrasi, para pihak dibebeaskan untuk memilih seorang arbiter yang menurut keyakinan mereka memiliki pengetahuan, pengalaman dan latar belakang yang cukup dan bisa dibilang akrab dengan masalah yang disengketakan, jujur dan adil. Para pihak juga dapat menentukan pilihan hukum untuk menyelesaikan masalah serta proses dan tempat arbitrase. Putusan arbitrase adalah putusan yang mengikat para pihak dan melalui prosedur yang sederhana dan langsung dapat dilaksanakan. ${ }^{13}$

Penyelesaian sengketa konsumen dimana para pihak memberikan penyelesaian kepada Majelis BPSK untuk memutuskan dan menyelesaikan sengketa yang terjadi. Proses melalui arbitrase ditempuh dalam dua tahap, tahap petama yaitu pihak yang memilih arbiter dari anggota BPSK yang berasal dari pelaku usaha dan konsumen sebagai anggota Dewan BPSK dan yang kedua yaitu arbiter yang dipilih oleh para pihak tersebut selanjutnya dapat memilih arbitor ketiga dari anggota BPSK dari pemerintah sebagai Ketua Dewan BPSK. Jadi tidak ada pemerintahan yang selalu terpilih menjadi Ketua MPR. Ketiga cara penyelesaian perselisihan atas permasalahan di atas dilakukan atas dasar pilihan dan kesepakatan para pihak yang berselisih dan bukan proses penyelesaian perselisihan.

Untuk alat-alat bukti yang dipergunakan di badan penyelesian sengketa konsumen yaitu barang atau jasa, adanya keterangan para pihak dan keterangan saksi dan saksi ahli, surat atau dokumen serta bukti-bukti lain yang mendukung. Dengan dasar Undang-Undang Perlindungan Konsumen, maka sistem pembuktian yang digunakan adalah sistem pembuktian terbalik. Sistem pembuktian terbalik dimaksud tercantum dalam Pasal 28 Undang-

11 Tami Rusli, "Penyelesaian Sengketa Antara Konsumen Dan Pelaku Usaha Menurut Peraturan Perundang-undangan”, https://core.ac.uk/download/pdf/324198782.pdf, Keadilan Progresif Vol. 3, no. 1, (Maret 2012).

${ }^{12}$ Undang-Undang Nomor 30 Tahun 1999 tentang Arbitrase dan Alternatif Penyelesaian Sengketa.

13 Ibid. 
Undang Nomor 8 Tahun 1999 tentang Perlindungan Konsumen yang selengkapnya adalah pembuktian terhadap ada dan tidaknya unsur kesalahan dalam gugatan ganti rugi. Pelaku usaha bertanggung jawab memberikan ganti rugi atas kerugian konsumen berupa pengembalian uang atau penggantian barang yang setara nilainya. Apabila pelaku usaha menolak untuk memenuhi ganti rugi maka akan digugat melalui BPSK atau mengajukan ke badan peradilam di tempat kedudukan konsumen.

Berdasarkan sistem pembuktian terbalik ini, maka beban pembuktian unsur kesalahan dalam gugatan ganti rugi konsumen menjadi beban dan tanggung jawab pelaku usaha. Konsekuensinya adalah jika pelaku usaha gagal membuktikan tidak adanya unsur kesalahan, maka gugatan ganti rugi penggugat (konsumen) akan dikabulkan. Adanya sistem pembuktian terbalik ini dalam Undang-Undang Perlindungan Konsumen dipandang sangat adil dan wajar, karena bila beban pembuktian itu dibebankan kepada penggugat (konsumen), sungguh sangat tidak adil, karena untuk membuktikan kesalahan pelaku usaha tidaklah mudah, disamping karena tingkat pengetahuan konsumen atas produk yang diahsilkan oleh pelaku usaha secara teknik laboratories tidak memadai, juga beratnya beban biaya pengajuan bukti-bukti yang harus ditanggung konsumen.

Hasil penyelesian sengketa baik secara konsiliasi maupun mediasi dituangkan dalam perjanjian tertulis dalam bentuk keputusan BPSK yang dilakukan selambat-lambatnya yaitu 21 hari kerja sejak permohonan diterima di sekretariat BPSK. Demikian pula dalam hal hasil penyelesaian sengketa konsumen dicapai melalui arbitrase, maka hasilnya dituangkan dalam bentuk keputusan BPSK yang ditandatangani oleh Ketua dan Anggota Majelis BPSK, dimana didalamnya diperkenankan menjatuhkan sanksi administratif.

Berdasarkan Pasal 39 SK Menperindag Nomor 350 / MPP / Kep /12/2001, proses dikeluarkan putusan BPSK dilakukan dengan tahapan-tahapan yang didasarkan atas musyawarah untuk mencapai mufakat yang melibatkan pihak-pihak dan BPSK. Jika hal itu sudah dilakukan secara sungguh-sungguh dan maksimal, ternyata tidak berhasil mencapai mufakat, maka putusan dilakukan dengan cara voting (suara terbanyak).

Upaya hukum terhadap putusan BPSK menentukan bahwa putusan majelis bersifat final dan mengikat. Dengan ini ditegaskan bahwa kata bersifat final itu berarti tidak ada upaya banding dan kasasi. Namun ternyata Undang-Undang Perlindungan Konsumen mengenal pengajuan keberatan terhadap putusan BPSK ke Pengadilan Negeri dan kasasi atas Putusan Pengadilan Negeri ke Mahkamah Agung. Dengan dimungkinkannya upaya hukum banding dan selanjutnya kasasi, maka sebenarnya pembentuk undang-undang bersikap tidak konsisten.

Dalam hal pelaku usaha menerima putusan BPSK, maka ia wajib melaksanakan putusan tersebut dalam waktu 7 hari kerja terhitung sejak menyatakan menerima putusan tersebut. Jika pelaku usaha tidak menggunakan upaya keberatan, maka putusan BPSK menjadi kekuatan hukum tetap. Terhadap putusan BPSK untuk dapat dilaksanakan secara paksa akan dimintakan fiat eksekusi dari Pengadilan Negeri di tempat kediaman konsumen, bila putusan BPSK tidak ditaati secara sukarela dan tidak diajukan upaya hukum. ${ }^{14}$

\section{SIMPULAN}

Bahwasannya masih banyak petani yang tergiur dengan pupuk bersubsidi yang dijual di pasaran. Padahal ketika petani melakukan pembelian pupuk bersubsidi tidak pada gerai kios resmi, keaslian pupuk bersubsidi tidak dapat terjamin. Akibatnya petani seringkali tertipu oleh oknum-oknum pelaku usaha yang tidak bertanggung jawab dengan memanfaatkna ketidaktahuan petani dan kurang hati-hati petani demi mendapatkan keuntungan yang besar.

1. Faktor yang menyebabkan terjadinya penjualan pupuk bersubsidi palsu adalah karena kurangnya kehati-hatian konsumen dalam pembelian pupuk bersubsidi, modal yang terbatas, tidak adanya tanggung jawab pelaku usaha, serta kemudahan dalam mendapatkan bahan baku pembuatan pupuk bersubsidi palsu di lapangan.

2. Mekanisme penyelesaian sengketa konsumen berdasarkan Undang-Undang Nomor 8 Tahun 1999 tentang Perlindungan Konsumen untuk membantu petani yang mengalami kerugian akibat membeli pupuk besubsidi palsu dengan cara mengajukan penyelesaian hukum terhadap penjual pupuk bersubsidi palsu melalui pelaporan pada Badan Penyelesaian Sengketa Konsumen (BPSK). Prosesnya melalui tiga cara yaitu konsilisi, mediasi, dan arbitrase. Hasil dari proses tersebut dapat mengganti kerugian yang dialami petani berupa uang dan penggantian pupuk serta sesuai dengan kesepakatan para pihak.

\section{DAFTAR PUSTAKA \\ Buku}

Muhammad, Abdulkadir. "Hukum dan Penelitian Hukum”, (Bandung: PT. Citra Aditya Bakti, 2004

Miru, Ahmadi. "Prinsip - prinsip Perlindungan Hukum Bagi Konsumen Di Indonesia", Jakarta: Rajawali Pers, 2013.

Rudy, Dr. Dewa Gde, dkk. "Buku Ajar Hukum Perlindungan Konsumen", Bali: Fakultas Hukum Universitas Udayana, 2016.

${ }^{14}$ Dr. Dewa Gde Rudy, dkk, Buku Ajar Hukum Perlindungan Konsumen. (Bali:Fakultas Hukum Universitas Udayana, 2016), hlm. 109. 
Safudin, Endrik. "Alternatif Penyelesaian Sengketa dan Arbitrase”, Jakarta: Instrans Publicing, 2017.

Pertanian, Kementrian. "Pedoman Pengawasan Pupuk dan Pestisida Tahun 2019", Direktorat Jenderal Prasarana dan Sarana Pertanian, 2019.

Marwan, M, dan Jimmy P. "Dictionary of Law Complete Edition Reality”, Yogyakarta: Reality Publiher, 2017.

Mamudji, Sri, dkk. "Metode Penelitian dan Penulisan Hukum", Jakarta: Badan Penerbit Fakultas Hukum Universitas Indonesia, 2005.

\section{Peraturan Perundang-undangan}

Undang-Undang Nomor 8 Tahun 1999 tentang Perlindungan Konsumen.

Undang-Undang Nomor 30 Tahun 1999 Tentang Arbitrase dan Alternatif Penyelesaian Sengketa.

\section{Jurnal}

Mairul dan Kartika Dewi Irianto, "Penyelesaian Sengketa Konsumen Melalui Jalur Non Litigasi (Studi pada Badan Penyelesaian Sengketa Konsumen (BPSK) dan Lembaga Alternatif Penyelesaian Sengketa (LAPS))", PAGARUYUANG Law Journal, Vol. 1, No. 2, (Januari 2018): P-ISSN: 2580-4227, E-ISSN: 2580-698X.

Mulyadi, Mohamad dan M. Edi Premono. "Pupuk Palsu : Penyebaran, Identifikasi Dan Dampaknya Terhadap Usaha Perkebunan", https://saraswantifertilizer.com/pupuk-palsu-penyebaran-identifikasi-dan-dampaknya-terhadapusaha-perkebunan/, PT. Saraswanti Anugerah Makmur - Saraswanti Group, (April 2018).

Rigi Nini, Syahrana Raesi, dan Rafnel Azhari. "Analisis Efektivitas Kebijakan Pupuk Bersubsidi Bagi Petani Di Nagari Cupak Kecamatan Gunung Talang Kabupaten Solok”, JOSETA: Journal Of Socio Economic on Tropical Agriculture, Vol. 1 No. 3, (Desember 2019): 75-83.

Rusli, Tami. "Penyelesaian Sengketa Antara Konsumen Dan Pelaku Usaha Menurut Peraturan Perundang-undangan", https://core.ac.uk/download/pdf/324198782.pdf, Keadilan Progresif Vol. 3, No. 1, (Maret 2012). 